\title{
ANALISIS DONGEN DANAU TOBA SEBAGAI BAHAN AJAR BAHASA INDONESIA
}

\section{Sri Dinanta Beru Ginting ${ }^{1}$, Kesya Meryan Sari Marpaung ${ }^{2}$, Wahyu Ningsih ${ }^{3}$ \\ Fakultas Keguruan dan Ilmu Pendidikan-Universitas Prima Indonesia \\ Corresponding Author: sridinanta_ginting@pnl.ac.id}

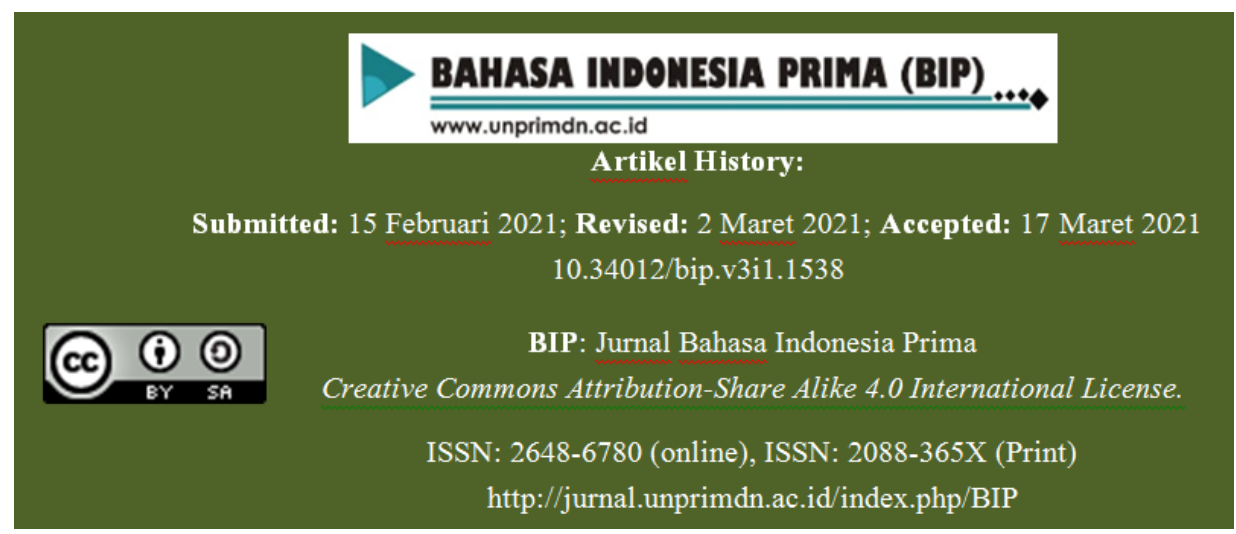

Abstrak-Dongeng merupakan salah satu cerita rakyat yang berjenis karya sastra sebagai khazanah budaya. Dongeng atau cerita rakyat sering dijadikan pedoman sebagi acuan yang mengandung nilai luhur mengenai budi pekerti sehingga sangat penting untuk dipelajari oleh generasi penerus Negara Indonesia. Dongeng diceritakan terutama untuk hiburan, walaupun banyak juga dongeng yang melukiskan kebenaran, berisi ajaran moral bahkan sindiran. Hasil dalam peelitian ini bahwa banyak terdapat nilai-nilai yang dapat diambil dari Dongeng atau cerita Danau Toba yang bisa dijadikan bahan ajar pelajaran Bahasa Indonesia yaitu nilai-nilai bahwa setiap ucapan yang di ucapkan sesuatu yang penting, mau berbuat dan mau bertanggung jawab dan orang tua kunci segalanya. Penelitian ini menggunakan teknik pengumpulan data dengan metode dokumenter, analisis data bersifat induktif. Data pada penelitian ini di dapat dari cerita atau dongeng Danau Toba.

Kata Kunci: Dongeng, Danau Toba, Bahan Ajar

\section{A. Pendahuluan}

Dongeng merupakan salah satu cerita rakyat yang berjenis karya sastra sebagai khazanah budaya. Menurut Bascom, dalam Dananjaya (2002) Dongeng termasuk dalam jenis cerita prosa rakyak selainmite (myte), dan juga legenda (legend). Cerita rakyat merupakan salah satu karya sastra yang pada zaman dahulu penyebarannya dilakukan secara turun-temurun, namun seiring perkembangan zaman serita rakyat atau dongen disuguhkan dalam bentuk tulisan sebagai bentuk pemeliharaan warisan leluhur yang diharapkan dapat diwariskan secara turun temurun (Alwi, 2003). Dongeng atau cerita rakyat sering dijadikan pedoman sebagi acuan yang mengandung nilai luhur mengenai budi pekerti sehingga sangat penting untuk dipelajari oleh generasi penerus Negara Indonesia.

Sering kali cerita dalam dongen tidak terikat pada waktu dan tempat, dapat terjadi dimana saja dan kapan saja tanpa perlu memperhatikan pelataran (Nurgiyantoro, 2005). Oleh karena itu, dongeng biasanya dimulai :"Pada suatu waktu hidup seorang", "Pada suatu hari", "Pada zaman dahulu atau pada dahulu kala", "Sahibul hikayat", "Di negeri antah berantah", "Di negara dongeng", dan sebagainya sedangkan kalimat penutup dongeng adalah, "dan mereka hidup bahagia untuk selama-lamanya." Meski digunakan untuk menghibur, dongeng dianggap melukiskan kebenaran dan moral, bahkan sindiran (Dananjaya, 2002 : 83) serta dipandang sarana ampuh 
mewariskan nilai-nilai (Nurgiyantoro, 2005 200). Selain itu, dongeng menurut Zipper (dalam Riris, 2009) berperan dalam menolong kita beradapatasi dengan lingkungan yang seringkali tidak ramah.

Melihat tujuan tersebut, dongeng sangat sesuai dijadikan sebagai bahan ajar Bahasa Indonesia. Tujuan inti materi dari bahan ajar dengan menggunakan dongeng ini adalah untuk mempelajari bahasa dan budaya Indonesia (Indonesia studies). Pengenalan dan pembelajaran bahasa Indonesia melalui sastra, khususnya cerita rakyat atau dongeng, sebagai bahan ajar pendukung akan lebih hidup dan menarik, serta memberikan warna yang berbeda dibandingkan dengan bahan inti yang biasanya bersifat formatif (Alaini dan Lestaringsih, 2014). Penggunaan dongeng sebagai bahan ajar tidak hanya meningkatkan pemahaman siswa terhadap budaya Indonesia tetapi juga akan meningkatkan pemahaman siswa terhadap bahasa Indonesia.

Penggunaan dongeng sebagai bahan ajar memberi impresi yang baik, menyenangkan, dan memperkaya kosakata. Penguasaan kosakata sangat mutlak dalam penguasaan bahasa. Selain sebagai alat ekspresi baik lisan maupun tulisan juga memperlancar komunikasi antar individu. Selain untuk menambah atau memperkaya pemahaman akan kosakata dan budaya Indonesia, penggunaan dongeng juga memungkinkan terjadinya interaksi budaya dalam pembelajaran Bahasa Indonesia.

Karya sastra sendiri memiliki pemaknaan tersendiri yang sangat penting bagi masyarakat yang mewakili setiap ide manusia pada masa lampau (Mahmud, 1997). Oleh karena itu, cerita rakyat atau dongeng penting untuk dikaji nilai-nilai yang terkandung didalamnya sehingga nantinya dapat dipahami dan dilaksanakan dalam menjalani kehidupan berbangsa dan bernegara. Dalam dunia pendidikan, menganalisis sebuah karya sastra sangat penting dilakukan untuk kepentingan pembelajaran bagi anak didik, selain berfungsi untuk bahan hiburan, karya sastra juga berfungsi sebagai bahan ajar bagi pembaca atau penikmatnya (Hasbullah, 2008). Karya sastra merupakan salah satu standar kompetensi yang harus dicapai oleh peserta didik untuk dapat mengembangkan kemampuan yang dimilikinya (Sapari, 2008).

Menurut Suyono (2009) pada studi Bahasa Indonesia, pengajaran dilakukan dengan melatih peserta didik untuk memiliki kemampuan seperti membaca, menulis, berbicara, mendengarkan, dan mengapresiasikan karya sastra sebagai tujuan untuk melatih peserta didik dalam meningkatkan potensi berbahasa Indonesia, baik lisan maupun tulisan. Oleh karena itu, dalam melakukan pembelajaran Bahasa Indonesia pendidik harus mengupayakan peningkatan kemampuan peserta didik untuk berkomunikasi secara lisan dan tulisan serta menghargai karya cipta bangsa Indonesia.

Pembelajaran Bahasa Indonesia dimana di dalamnya terdapat pembelajaran tentang karya sastra hendaknya diajarkan melalui cerita atau dongeng hal ini dikarenakan agar peserta didik dapat merasakan kesenangan, mengalami petualangan, dan mencerna sendiri maknamakna yang hendak disampaikan melalui cerita dongeng tersebut yang pada akhirnya mereka akan mampu memahami diri sendiri dan orang lain. Salah satu dongen atau cerita rakyat yang terkenal adalah Dongeng Danau Toba yang didalamnya terdapat banyak nilai serta norma yang dapat dijadikan pedoman dalam menjalani kehidupan sehari-hari.

Berdasarkan latar belakang yang telah di paparkan tersebut maka rumusan masalah dalam penelitian ini adalah a) Bagaimana nilai moral yang terdapat di dalam cerita atau dongeng Danau Toba diaplikasikan dalam pembelajaran Bahasa Indonesia? dan (b) Bagaimana nilai kerja keras dalam cerita atau dongeng Danau Toba diaplikasikan dalam pembelajaran Bahasa Indonesia? 


\section{B. Metode penelitian}

\section{Rancangan Penelitian}

Penelitian ini menggunakan studi literatur dan kualitatif deskriptif. Menurut Sugiyono (2009) penelitian kualitatif merupakan penelitian yang lebih menekankan pada makna generalisasi. Data yang dihasilkan pada penelitian ini berupa kata-kata yang berbentuk uraian serta kutipan baik kutipan langsung maupun kutipan tidak langsung. Menurut Moleong (2006) penelitian kualitatif lebih mengutamakan kedalaman dan penghayatan terhadap interaksi antar konsep yang dikaji secara empiris. Sedangkan pada metode yang bersifat deskriptif, data diuraikan dalam bentuk kata-kata yang bertujuan untuk memberikan suatu pemahaman yang lebh komprehensif (Semi, 1999).

Data yang diperoleh, selanjutnya dianalisis dengan metode deskriptif untuk menjabarkan fakta-fakta yang kemudian dapat memberikan pemahaman dan penjelasan. Data yang digunakan oleh penulis pada penelitian ini adalah dengan melakukan observasi dan merujuk pada data yang diperoleh dari jurnal, buku, serta sumber pustaka lainnya.

\section{Sumber Data}

Pada penelitian ini sumber data yang digunakan adalah dongeng "Danau Toba" yang terdapat dalam buku teks Bahasa Indonesia SMP kelas VII terbitan Pusat Perbukuan Departemen Pendidikan Nasional.

\section{Teknik Pengumpulan Data}

Teknik pengumpulan data dilakukan dengan teknik studi pustaka. Menurut Hadiyandra (Maria, 2002) Studi pustaka adalah "Kegiatan yang berupa pemerolehan bahan atau informasi dari buku-buku, makalah, artikel, dan bahan bacaan dari majalah atau koran". Data penelitian ini adalah nilai pendidikan religius yang terdapat dalam dongeng dalam buku teks Bahasa Indonesia kelas VII terbitan Pusat Perbukuan Departemen Pendidikan Nasional, karya Nila Kuriniati Sapari, terbitan tahun 2008.

\section{Teknik Analisis Data}

Untuk menganalisis data pada penelitian ini digunakan teknis analisis karya. Menurut GorysKeraf dalam Suwanda, (2007) "Analisis karya adalah suatu metode penyelidikan dengan mengadakan penelitian atau penganalisisan dari hasil karya terkenal dalam suatu bidang pengatahuan".

\section{Hasil dan Pembahasan}

Pemilihan dongen dapat disesuaikan dengan usia siswa serta jenjang pendidikannya, keran hal tersebut akan sangat erat kaitannya dengan isi cerita yang disampaikan. Bentuk evaluasi pun dapat disesuaikan dengan jenjang atau tingkatan siswa agar tingkat pemahaman siswa dapat tercapai secara maksimal (Alaini dan Lestariningsih, 2014). Pemilihan dongeng atau cerita rakyat pada penelitian ini sebagai bahan ajar pembelajaran Bahasa Indonesia menggunakan dongeng Danau Toba. Berikut merupakan dongen Danau Toba (Sarwiji, dan Sutarmo, 2008):

\section{DANAU TOBA}

Dikisahkan di sebuah desa di wilayah Sumatera Utara, hiduplah seorang yang bernama Toba. Ia seorang Toba yang rajin bekerja walaupun lahan pertaniannya tidak luas. Ia bisa mencukupi kebutuhannya dari hasil kerjanya yang tidak kenal lelah. Sebenarnya usianya sudah cukup untuk menikah, tetapi ia tetap memilih hidup sendirian. Di suatu pagi hari yang cerah, Toba itu memancing ikan di sungai. Setelah kailnya dilemparkan, kailnya terlihat bergoyang-goyang. Ia segera menarik kailnya. Toba itu bersorak kegirangan setelah mendapat seekor ikan cukup besar.

Toba sangat takjub saat melihat warna sisik ikan yang indah. Sisik ikan itu berwarna kuning emas kemerah-merahan. Kedua matanya bulat dan menonjol memancarkan kilatan yang menakjubkan. "Tunggu, aku jangan dimakan! Aku akan bersedia menemanimu jika kau tidak jadi memakanku." Toba tersebut terkejut mendengar suara dari ikan itu. Karena 
keterkejutannya, ikan yang ditangkapnya terjatuh ke tanah. Kemudian tidak berapa lama, ikan itu berubah wujud menjadi seorang gadis yang cantik jelita. "Bermimpikah aku?," gumam Toba.

Setelah sampai di desanya, gemparlah penduduk desa melihat gadis cantik jelita bersama Toba tersebut. "Dia mungkin bidadari yang turun dari langit," gumam mereka. Toba merasa sangat bahagia dan tenteram. Sebagai suami yang baik, ia terus bekerja untuk mencari nafkah dengan mengolah sawah dan ladangnya dengan tekun dan ulet. Karena ketekunan dan keuletannya, Toba itu hidup tanpa kekurangan dalam hidupnya. Banyak orang iri, dan mereka menyebarkan sangkaan buruk yang dapat menjatuhkan keberhasilan usaha Toba. "Aku tahu Toba itu pasti memelihara makhluk halus! " kata seseorang kepada temannya. Hal itu sampai ke telinga Toba dan Puteri. Namun mereka tidak merasa tersinggung, bahkan semakin rajin bekerja.

Setahun kemudian, kebahagiaan Petan dan istri bertambah, karena istri Toba melahirkan seorang bayi laki-laki. Ia diberi nama Samosir. Kebahagiaan mereka tidak membuat mereka lupa diri. Samosir tumbuh menjadi seorang anak yang sehat dan kuat. Ia menjadi anak manis tetapi agak nakal. Ia mempunyai satu kebiasaan yang membuat heran kedua orang tuanya, yaitu selalu merasa lapar. Makanan yang seharusnya dimakan bertiga dapat dimakannya sendiri.

Lama kelamaan, Samosir selalu membuat jengkel ayahnya. Jika disuruh membantu pekerjaan orang tua, ia selalu menolak. Istri Toba selalu mengingatkan Toba agar bersabar atas ulah anak mereka. "Ya, aku akan bersabar, walau bagaimanapun dia itu anak kita!" kata Toba kepada istrinya. "Syukurlah, kanda berpikiran seperti itu. Kanda memang seorang suami dan ayah yang baik," puji Puteri kepada suaminya.

Memang kata orang, kesabaran itu ada batasnya. Hal ini dialami oleh Toba itu. Pada suatu hari, Samosir mendapat tugas mengantarkan makanan dan minuman ke sawah di mana ayahnya sedang bekerja. Tetapi Samosir tidak memenuhi tugasnya. Toba menunggu kedatangan anaknya, sambil menahan haus dan lapar. Ia langsung pulang ke rumah. Di lihatnya Samosir sedang bermain bola. Toba menjadi marah sambil menjewer kuping anaknya. "Anak tidak tau diuntung! Tak tahu diri! Dasar anak ikan!," umpat si Toba tanpa sadar telah mengucapkan kata pantangan itu.

Setelah Toba mengucapkan katakatanya, seketika itu juga anak dan istrinya hilang lenyap. Tanpa bekas dan jejak. Dari bekas injakan kakinya, tibatiba menyemburlah air yang sangat deras dan semakin deras. Desa Toba dan desa sekitarnya terendam semua. Air meluap sangat tinggi dan luas sehingga membentuk sebuah telaga. Dan akhirnya membentuk sebuah danau. Danau itu akhirnya dikenal dengan nama Danau Toba. Sedangkan pulau kecil di tengahnya dikenal dengan nama Pulau Samosir. (Pulungan, 2019).

\section{a) Analisis Instrinsik}

Tema: Kemarahan seorang ayah karena tingkah anaknya. Hal ini dialami oleh Toba dimana pada suatu hari, Samosir mendapat tugas mengantarkan makanan dan minuman ke sawah di mana ayahnya sedang bekerja. Tetapi Samosir tidak memenuhi tugasnya. Toba menunggu kedatangan anaknya, sambil menahan haus dan lapar. Ia langsung pulang ke rumah. Di lihatnya Samosir sedang bermain bola. Toba menjadi marah sambil menjewer kuping anaknya. "Anak tidak tau diuntung! Tak tahu diri! Dasar anak ikan!," umpat si Toba tanpa sadar telah mengucapkan kata pantangan itu. Setelah Toba mengucapkan katakatanya, seketika itu juga anak dan istrinya hilang lenyap. Tanpa bekas dan jejak. Dari bekas injakan kakinya, tibatiba menyemburlah air yang sangat deras dan semakin deras.

Desa Toba dan desa sekitarnya terendam semua. Air meluap sangat tinggi dan luas sehingga membentuk sebuah 
telaga. Dan akhirnya membentuk sebuah danau. Danau itu akhirnya dikenal dengan nama Danau Toba. Sedangkan pulau kecil di tengahnya dikenal dengan nama Pulau Samosir. Alasan: karena kesal dengan kelakuan anaknya yang menghabiskan makanannya. Sehingga ia kehilangan kesabaran, dan marah pada anaknya dan mengucapkan kata pantangan yang tidak seharusnya ia katakan. Gambaran dari alasan dari tema yang terjadi dari dongeng Danau Toba yaitu bahwa memang kata orang, kesabaran itu ada batasnya. Hal ini dialami oleh Toba itu. Pada suatu hari, Samosir mendapat tugas mengantarkan makanan dan minuman ke sawah di mana ayahnya sedang bekerja. Tetapi Samosir tidak memenuhi tugasnya. Toba menunggu kedatangan anaknya, sambil menahan haus dan lapar. Ia langsung pulang ke rumah. Di lihatnya Samosir sedang bermain bola. Toba menjadi marah sambil menjewer kuping anaknya. "Anak tidak tau diuntung! Tak tahu diri! Dasar anak ikan!," umpat si Toba tanpa sadar telah mengucapkan kata pantangan itu.

Setelah Toba mengucapkan katakatanya, seketika itu juga anak dan istrinya hilang lenyap. Tanpa bekas dan jejak. Dari bekas injakan kakinya, tibatiba menyemburlah air yang sangat deras dan semakin deras. Desa Toba dan desa sekitarnya terendam semua. Air meluap sangat tinggi dan luas sehingga membentuk sebuah telaga. Dan akhirnya membentuk sebuah danau. Danau itu akhirnya dikenal dengan nama Danau Toba. Sedangkan pulau kecil di tengahnya dikenal dengan nama Pulau Samosir.

\section{b) Analisis Amanat}

Amanat: Sebagai seorang anak janganlah suka melawan dan membangkang pada orang tua. Dan sebagai orang tua jangan suka marah dan mengucapkan kata-kata yang tidak baik kepada anak.

Latar Tempat : Desa

Latar Waktu : Pagi Hari

Latar Suasana : Menegangkan
Gambaran latar waktu, latar tempat dan latar suasana dapat dilihat dari kutipan dongeng berikut : Di sebuah desa di wilayah Sumatera, hidup seorang Toba. Ia seorang Toba yang rajin bekerja walaupun lahan pertaniannya tidak luas. Ia bisa mencukupi kebutuhannya dari hasil kerjanya yang tidak kenal lelah. Sebenarnya usianya sudah cukup untuk menikah, tetapi ia tetap memilih hidup sendirian.

Di suatu pagi hari yang cerah, Toba itu memancing ikan di sungai. "Mudahmudahan hari ini aku mendapat ikan yang besar," gumam Toba tersebut dalam hati. Beberapa saat setelah kailnya dilemparkan, kailnya terlihat bergoyang-goyang. Ia segera menarik kailnya. Toba itu bersorak kegirangan setelah mendapat seekor ikan cukup besar. Lama kelamaan, Samosir selalu membuat jengkel ayahnya. Jika disuruh membantu pekerjaan orang tua, ia selalu menolak. Istri Toba selalu mengingatkan Toba agar bersabar atas ulah anak mereka. "Ya, aku akan bersabar, walau bagaimanapun dia itu anak kita!" kata Toba kepada istrinya. "Syukurlah, kanda berpikiran seperti itu. Kanda memang seorang suami dan ayah yang baik," puji Puteri kepada suaminya. Memang kata orang, kesabaran itu ada batasnya. Hal ini dialami oleh Toba itu. Pada suatu hari, Samosir mendapat tugas mengantarkan makanan dan minuman ke sawah di mana ayahnya sedang bekerja. Tetapi Samosir tidak memenuhi tugasnya.

Toba menunggu kedatangan anaknya, sambil menahan haus dan lapar. Ia langsung pulang ke rumah. Di lihatnya Samosir sedang bermain bola. Toba menjadi marah sambil menjewer kuping anaknya. "Anak tidak tau diuntung ! Tak tahu diri ! Dasar anak ikan !," umpat si Toba tanpa sadar telah mengucapkan kata pantangan itu. Setelah Toba mengucapkan katakatanya, seketika itu juga anak dan istrinya hilang lenyap. Tanpa bekas dan jejak. Dari bekas injakan kakinya, tibatiba menyemburlah air yang sangat deras dan semakin deras. Desa Toba dan desa 
sekitarnya terendam semua. Air meluap sangat tinggi dan luas sehingga membentuk sebuah telaga. Dan akhirnya membentuk sebuah danau. Danau itu akhirnya dikenal dengan nama Danau Toba. Sedangkan pulau kecil di tengahnya dikenal dengan nama Pulau Samosir.

\section{c) Analisis Penokohan}

\section{Tokoh Toba}

Toba: Baik, Kasar

Gambaran tokoh Toba dalam dongeng Danau Toba dapat dilihat dari kutipan berikut:

Di sebuah desa di wilayah Sumatera, hidup seorang Toba. Ia seorang Toba yang rajin bekerja walaupun lahan pertaniannya tidak luas. Ia bisa mencukupi kebutuhannya dari hasil kerjanya yang tidak kenal lelah. Sebenarnya usianya sudah cukup untuk menikah, tetapi ia tetap memilih hidup sendirian. Di suatu pagi hari yang cerah, Toba itu memancing ikan di sungai. "Mudah-mudahan hari ini aku mendapat ikan yang besar," gumam Toba tersebut dalam hati. Beberapa saat setelah kailnya dilemparkan, kailnya terlihat bergoyang-goyang. Ia segera menarik kailnya.

Toba itu bersorak kegirangan setelah mendapat seekor ikan cukup besar.

Ia takjub melihat warna sisik ikan yang indah. Sisik ikan itu berwarna kuning emas kemerahmerahan. Kedua matanya bulat dan menonjol memancarkan kilatan yang menakjubkan. "Tunggu, aku jangan dimakan! Aku akan bersedia menemanimu jika kau tidak jadi memakanku." Toba terkejut mendengar suara dari ikan itu. Karena keterkejutannya, ikan yang ditangkapnya terjatuh ke tanah. Kemudian tidak berapa lama, ikan itu berubah wujud menjadi seorang gadis yang cantik jelita. "Bermimpikah aku?," gumam Toba. Lama kelamaan, Samosir selalu membuat jengkel ayahnya. Jika disuruh membantu pekerjaan orang tua, ia selalu menolak. Istri Toba selalu mengingatkan Toba agar bersabar atas ulah anak mereka. "Ya, aku akan bersabar, walau bagaimanapun dia itu anak kita!" kata Toba kepada istrinya.
"Syukurlah, kanda berpikiran seperti itu. Kanda memang seorang suami dan ayah yang baik," puji Puteri kepada suaminya.

\section{Tokoh Samosir}

Samosir: Baik, Degil

Gambaran tokoh Samosir dalam dongeng Danau Toba dapat dilihat dari kutipan berikut:

Kebahagiaan mereka tidak membuat mereka lupa diri. Samosir tumbuh menjadi seorang anak yang sehat dan kuat. Ia menjadi anak manis tetapi agak nakal. Ia mempunyai satu kebiasaan yang membuat heran kedua orang tuanya, yaitu selalu merasa lapar. Makanan yang seharusnya dimakan bertiga dapat dimakannya sendiri. Lama kelamaan, Samosir selalu membuat jengkel ayahnya. Jika disuruh membantu pekerjaan orang tua, ia selalu menolak. Istri Toba selalu mengingatkan Toba agar bersabar atas ulah anak mereka. "Ya, aku akan bersabar, walau bagaimanapun dia itu anak kita!" kata Toba kepada istrinya. "Syukurlah, kanda berpikiran seperti itu. Kanda memang seorang suami dan ayah yang baik," puji Puteri kepada suaminya.

\section{Tokoh Putri}

Putri: Baik, Ramah

Gambaran tokoh putri dalam dongeng Danau Toba dapat dilihat dari kutipan berikut:

Ia takjub melihat warna sisik ikan yang indah. Sisik ikan itu berwarna kuning emas kemerahmerahan. Kedua matanya bulat dan menonjol memancarkan kilatan yang menakjubkan. "Tunggu, aku jangan dimakan! Aku akan bersedia menemanimu jika kau tidak jadi memakanku." Toba terkejut mendengar suara dari ikan itu. Karena keterkejutannya, ikan yang ditangkapnya terjatuh ke tanah. Kemudian tidak berapa lama, ikan itu berubah wujud menjadi seorang gadis yang cantik jelita. "Bermimpikah aku?," gumam Toba.

"Jangan takut pak, aku juga manusia seperti engkau. Aku sangat berhutang budi padamu karena telah menyelamatkanku dari kutukan Dewata," kata gadis itu. "Namaku Puteri, aku tidak keberatan untuk menjadi istrimu," kata gadis itu 
seolah mendesak. Toba itupun mengangguk. Maka jadilah mereka sebagai suami istri. Namun, ada satu janji yang telah disepakati, yaitu mereka tidak boleh menceritakan bahwa asal-usul Puteri dari seekor ikan. Jika janji itu dilanggar maka akan terjadi petaka dahsyat.

\section{Analisis Alur}

a. Awal: Toba memancing ikan lalu mendapat seekor ikan yang cantik yang merupakan jelmaan dari seorang gadis cantik. Kemudian mereka menikah dan memiliki seorang anak.

b. Tengah: setelah kelahiran anak mereka yang merupakan seorang anak lelaki kebahagiaan mereka semakin bertambah. Anak mereka diasuh dengan sangat baik. Anak mereka tumbuh menjadi anak yang sehat. Namun ia sangat suka makan, hingga suatu hari ia memakan makanan ayahnya.

c. Akhir: ketika Samosir di mendapat tugas mengantar makanan untuk ayahnya di sawah, tiba-tiba ia merasa lapar kemudian memakan makanan yang seharusnya untuk sang ayah. Melihat semua makanan sudah habis. Toba merasa sangat marah kemudian memarahi anaknya dan mengatakan kata-kata yang seharusnya tidak ia ucapkan. Kalimat yang ia ucapkan menjadi petaka baginya dan keluarganya, bahkan seluruh penduduk di desa tempat tinggalnya

\section{Analisis Nilai-Nilai}

Berdasarkan cerita dongen Danau Toba dapat diambil nilai moral yang harus diterapkan pada pembelajaran Bahasa Indonesia yaitu kita sebagai manusia harus memiliki budi pekerti, rasa sopan dan hormat pada semua orang terutama oarang tua. Dari cerita atau dongeng ini maka dapat diajarkan kepada anak-anak untuk memiliki rasa sopan dan hormat kepada semua orang terutama kepada orang tua. Karena orang tua mempunyai peranan penting dalam membesarkan dan mendidik anakanaknya. Sehingga dari cerita dongeng ini dapat lah diambil hikmah yang banyak dalam mendidik anak.

Selanjutnya nilai sosial yang dapat kita simpulkan dan terapkan dalam pembelajaran Bahasa Indonesia adalah bahwa kita tidak boleh mau menang sendiri dan egois pada orang lain terutama orang tua dan harus mau berbagi. Dari cerita ini dapat kita lihat bahwa nilai sosial yang terdapat dalam dongeng ini sangat banyak terutama tidak boleh egois dan mementingkan diri sendiri. Kita harus berbagi dengan sesama. Dan selalu bersikap baik kepada siapa saja.

Kemudian nilai budaya yang dapat kita terapkan sebagai bahan ajar Bahasa Indonesia adalah bahwa kita harus mau mencintai dan menerima budaya kita dan terutama orang tua. Dari nilai budaya yang ada dalam dongeng ini kecintaan anak terhadap kebudayaan Indonesia harus di lestarikan. Karena dengan mencintai dan menjaga budaya kita maka kita telah melestarikan budaya Indonesia (Kusyanti, 2008).

Selanjutnya nilai yang dapat kita jadikan acuan untuk bahan ajar pembelajaran Bahasa Indonesia adalah bahwa nilai kerja Keras Nilai kerja keras dalam dongeng ini dapat kita lihat dari tokoh-tokohnya.

\section{Analisis Sosial}

Berdasarkan penelitian yang dilakukan terhadap dongeng Danau Toba pada analisis sosial, ciri-ciri yang tampak pada dongeng Danau Toba ini adalah sebagai berikut:

a. Cerita tersebut memberi pelajaran dan nasehat

b. Tidak ada nama pengarang

c. Tidak jelas waktu terjadinya peristiwa yang di ceritakan pada dongeng Danau Toba.

d. Asal cerita dongeng Danau Toba yakni dari Sumetera Utara

7. Penaranan Dongeng Danau Toba sebagai Bahan Ajar

Dalam cerita dongeng Danau Toba siswa banyak mendapatkan pembelajaran 
karena banyak nilai-nilai moral, nilai sosial, dan nilai budaya yang dapat dipelajari dan di terapkan siswa dalam kehidupannya sehari-hari. Pelajaran Bahasa Indonesia merupakan mata pelajaran umum yang diajarkan kepada siswa dari tingkatan Sekolah Dasar hingga Perguruan Tinggi. Melalui belajar dongeng siswa dapat memperkaya kosakata sehingga dapat meningkatkan kemampuannya dalam berkomunikasi baik secara lisan maupun tulisan.

Tingkatan dan kompetensi pemahaman siswa yang digunakan pada penelitian ini mengacu pada Common European Frame Work of Referance for Langguages (CEFR), yang mana tingkatan dan kompetensi pemahaman siswa ini terdiri dari tiga tingkatan yakni, 1). Tingkat Pemula, 2) Tingkat Madya, dan 3). Tingkat Lanjut (Muliatuti, 2017).

\section{Tingkat Pemula}

Pada tingkat pemula dongengdongeng yang dapat digunakan sebagai bahan ajar adalah dongeng-dongeng klasik. Dongeng-dongeng klasik yang digunakan merupakan dongeng yang berasal dari daerah asalnya yang memiliki keseragaman tife baik plot maupun karakter tokohnya. Selain itu kita juga dapat mengetahui pengaruh dari beberapa peradaban besar seperti Hindu, islam dan cina yang menyebabkan banyak dongeng di Indonesia memiliki tife yang sama (Dananjaya, 2002). Istilah tifa dalam kajian ini digunakan untuk mengklasifikasikan sistem pengarsipan dongeng. Tife-tife yang dapat digunakan dalam pembelajaran pada tingkat pemula ini seperti tingkat binatang cerdik yang menjadi lawan binatang lainnya seperti " $\mathrm{Si}$ Kancil”.

Pada pembelajaran dongeng di tingkat pemula ini siswa dapat mencari dongengdongeng yang berasal dari asal daerahnya masing-masing, kemudian siswa diminta untuk menceritakannya kembali sesuai dengan pemahaman dan bahasanya sendiri. Selanjutnya siswa dapat berdiskusi dengan siswa lainnya untuk mencari perbandingan antara dongeng dari daerah yang satu dengan daerah lainnya.

Selain itu untuk memaksimalkan pememahaman siswa dalam kegiatan pembelajaran dapat menggunakan video atau gambar tentang dongeng-dongeng yang dipilih. Melalui pembelajaran ini diharapkan siswa dapat melatih kosakata, ekspresi dan komunikasi. Pemahaman budaya yang terbentuk akan meningkatkan toleransi dan kepekaan sosial pasa setiap siswa.

\section{Tingkat Madya}

Pada tingkatan madya pengajar akan menyajikan dongen modern yang mana ceritanya sengaja dikreasikan oleh pengarang. Dongeng ini sengaja ditulis sebagai suatu dongeng, karya-karya fantansi namun tetap menampilkan polapola naratif cerita rakyat (Nurgiyantoro, 2005). Contoh dongeng-dongeng modern seperti : "Dongeng Putri Kemang dari Bengkulu, Dongeng Mengapa Tubuh Udang Bengkok dari Kalimantan Tengah, Si Molek : Cerita rakyat dari riuau, serta Kancil dan Kura-Kura dari Kalimantan Barat."

Selanjutnya pengajar akan menampilkan dongeng tersebut di kelas atau menampilkan videonya. Setelah itu, pengajar memberikan pertanyaan yang dapat dijawab, maupun dikomentari oleh siswa. Dalam aktivitas ini, apapun isi dari tanggapan siswa atas pertanyaan yang di ajukan oleh guru tidak dinilai benar atau salah, maupun baik-buruknya. Hal ini dikarenakan masalah tersebut bukan suatu hal yang ingin di capai dalam kegiatan pembelajaran, melainkan tujuan yang ingin dicapai adlah agar siswa mampu melatih keberanian diri untuk menyampaikan pendapatnya di depan kelas (Nurhuda, dkk. 2017).

Dengan tahapan kegiatan seperti itu diharapkan siswa dapat mampu mempelajari atau memahami teks kompleks serta mampu berinteraksi dengan teman-teman di kelasnya dengan baik, spontan dalam berdiskusi. Setelah itu, siswa dapat menulis cerita sederhana 
BIP: Jurna Bahasa Indonesia Prima,

Vol 3, No. 1, 2021, Maret 2021, pp.

yang sesuai dengan topik yang sedang dibahas dengan mengaitkan dengan pengalamannya, serta menyampaikan sudut pandang yang berada pada topiktopik yang dibahas.

\section{Tingkat Lanjut}

Pada tingkat lanjut, pembelajaran dongeng dapat dilakukan secara lebih impresif dan menyenangkan, namun tetap dapat memperkaya kosakata setiap siswanya. Penguasaan kosakata sangat mutlak dalam penguaasaan bahasa. Selain itu bahasa juga dapat menjadi sebagai alat ekspresi baik secara lisan maupun tulisan. Pada tingkatan ini siswa dapat memainkan imajinasinya. Dongeng-dongeng klasik yang terkenal oleh siswa dapat diubah bagian akhirnya sesuai dengan imajinasi masing-masing siswa

\section{SIMPULAN}

Dongeng atau cerita Danau Toba dapat dijadikan acuan dalam pembelajaran Bahasa Indonesia karena mengandung nilai-nilai bahwa setiap ucapan yang di ucapkan sesuatu yang penting, mau berbuat dan mau bertanggung jawab dan orang tua kunci segalanya. Selain itu untuk meningkatkan kompetensi kebahasaan yang mencakup keterampilan menyimak, bebicara, membaca, dan menulis juga mengenalkan dongeng sebagai merupakan unsur budaya Indonesia. Pemahaman budaya akan meningkatkan interaksi budaya sehingga akan menimbulkan toleransi yang mempermudah dalam proses pembelajaran Bahasa Indonesia.

Saran yang dapat diberikan berdasarkan hasil penelitian inidiharapkan pembaca agar selalu memperhatikan ucapan dan selalu berpegang teguh pada apa yang telah kita ucapkan. Dan selalubertanggungjawab dengan segala hal yang telah kita perbuat.

DAFTAR PUSTAKA

Alwi, H. 2007. Kamus Besar Bahasa Indonesia Edisi Revisi. Jakarta: Balai Pustaka.
Dananjaya, J. 2002. Faktor Indonesia Ilmu Gosip, Dongeng, dan Lain-lain. Jakarta: Grafiti.

Hasbullah. 2008. Dasar- Dasar Ilmu Pendidikan. Jakarta: Raja Grafindo Persada.

Kusyanti, Y. 2008. Nilai Budaya Dalam Penuturan Senandung Jolo Di DesaTanjung Kecamatan Kumpeh Kabupaten Muaro Jambi. Jambi: PBS FKIPUniversitas Jambi.

Mahmud, A. 1997. Analisis Struktur dan Nilai Budaya. Jakarta : Departemen Pendidikan dan Kebudayaan

Moleong, L. 2006. Metodologi Penelitian Kualitatif. Bandung: Remaja Rosdakarya.

Nurhuda, T. A., Herman, J. W., \& Suyitno. 2017. Pemanfaatan Sastra Sebagai Bahan Ajar Pengajaran Sastra. The 11st Eduational an Language International Conference Proceedings. Center for International Language Development of Uninsula.

Nurgiantoro, B. 2005. Sastra Anak Pengantar Pemahaman Dunia Anak. Yogyakarta: Gajah Mada University Press.

Pulungan, R. 2019. Analisis Dongen Danau Toba pada Buku Teks Bahasa Indonesia Kelas VII Terbitan Pusat Perbukuan Departemen Pendidikan Nasional. Prosiding Seminar Nasional \& Expo II. Hasil Penelitian dan Pengabdian Masyarakat.

Sapari, N. K. 2008. Kompetensi Berbahasa Indonesia. Semarang: Ghyass Putra

Sarwiji S. dan Sutarmo. 2008. Buku Teks Bahasa Indonesia Kelas VII SMP. Jakarta: Pusat Perbukuan Departemen Pendidikan Nasional. 
BIP: Jurna Bahasa Indonesia Prima,

Vol 3, No. 1, 2021, Maret 2021, pp.

Semi, M. A. 1999. Metode Penelitian Sastra. Bandung: Pustaka.

Sugiyono. 2009. Memahami Penelitian Kualitatif. Bandung: Alfabeta
Suyono. 2009. Cerdas Berfikir Bahasa dan Sastra Indonesia Kelas X SMA. Bandung: Ganesa Exact. 